\title{
Isolation of endophytic actinomycetes from roots and leaves of maize (Zea mays L.)
}

\author{
Janete M. de Araújo ${ }^{1}$, Adilson C. da Silva ${ }^{2}$ and João L. Azevedo ${ }^{2 *}$ \\ ${ }^{1}$ Departamento de Antibióticos, Universidade Federal de Pernambuco, 50670-901, Recife - PE, Brazil; ${ }^{2}$ Escola \\ Superior de Agricultura "Luiz de Queiroz", Universidade de São Paulo, Caixa postal 83 - 13400-970, Piracicaba - \\ SP, Brazil
}

\begin{abstract}
Actinomycetes were isolated from surface sterilized leaves and roots of maize. A total of 53 isolates were obtained, 31 of them from leaves and 22 from roots. The genus Microbispora was the most frequently found followed by the genera Streptomyces and Streptosporangium. From the isolated actinomycetes, $43.4 \%$ showed antimicrobial activity against one or more tested bacteria and yeast.
\end{abstract}

Key words: Endophytes, maize, actinomycetes, Microbispora, Streptomyces, Streptosporangium

\section{INTRODUCTION}

Endophytic microorganisms are those which inhabitat the internal part of plants, causing apparently no visible changes to their hosts. Although known since long time, their importance become evident only more recently when it was shown that they play specific roles as for instance, protecting the host-plants against insects and diseases. It has been found also that some endophytic microorganisms can produce valuable pharmaceutical substances of biotechnological interest (Strobel et al, 1996; Strobel \& Long, 1998). The main roles of endophytic microorganisms are discussed in the reviews of ISaac (1992), Redlin \& Carris (1996), Baldani et al (1997) and Azevedo (1998).

Actinomycetes are bacteria known to constitute a large part of the rhizosphere microbiota. Their isolation is an important step for screening of new bioactive compounds. Actinomycetes are also found inside plants but, excluding the coryneform bacteria, the only extensively studied species are from the genus Frankia, a nitrogen fixing bacteria of non-leguminous plants (Benson \& Silvester, 1993) and a few species of the genus Streptomyces that are phytopathogens (Bradbury, 1986). Mundt \& Hinckle (1976) isolated the genera Nocardia and Streptomyces from seed and ovules of 27 plant species. Sardi et al. (1992) isolated and observed by direct microscope examination endophytic actinomycetes from the roots of 28 plant species from the northwestern Italy. Most of the isolates were classified as Streptomyces but the genera Streptoverticillium, Nocardia, Micromonospora and Streptosporangium were also found. More recently Matsukuma et al, (1995) isolated few actinomycetes from leaves of Camellia japonica and citrus, Maitan (1998) observed rare actinomycetes isolated as endophytes of Solanum lycocarpum in middlewest Brazil and Matsumoto et al (1998) isolated also actinomycetes from fallen leaves and the genus Microbispora was the most frequently found, accounting for $44 \%$ of all isolates.

The presence of endophytic microorganisms in healthy crops has been demonstrated in maize. Although several fungi and bacteria species were reported, no actinomycetes were isolated (Fisher $e t$ al, 1992, Souza, 1996; Silva, 1997) and so far, no studies have been undertaken to assess the incidence of endophytic actinomycetes of this important species. The present work was carried out to isolate actinomycetes from roots and leaves of a variety of maize designated Piranão, widely cultivated in Brazil. Also the isolated actinomycetes were screened for antibiotic production against one yeast and three bacteria.

\footnotetext{
* Author for correspondence
} 


\section{MATERIALS AND METHODS}

Plant material : Seeds from the Zea mays variety Piranão were planted in a non fertilized soil, free from insecticides and other chemicals in an experimental field of the "Universidade Federal de Pernambuco ", Recife, located in a tropical area in the northeast Brazil during the summer and plants were sampled 7, 14 and 21 days after the emergence. Only plants exhibiting healthy vegetative growth were used.

External sterilization of leaves and roots: Two leaves and two segments of roots from each collected plant were used. Samples were sterilized according to FISHER et al. (1992) with modiifications (PEREIRA et al.,1993; 1999). They were washed in water following surface sterilization with ethanol $70 \%$ for 30 seconds and then treated with sodium hypochloride (3\%-5\% available chlorine) for 3 minutes. Samples were exaustively rinsed with sterile water. Sterility checks and reconstruction experiments showed that most or all epiphytic microorganisms were eliminated during this treatment. Each root was divided into pieces of ca. $1 \mathrm{~cm}$ and each leaf was divided into fragments of about $1 \mathrm{~cm}^{2}$. Root and leaf fragments were assepticaly transferred to petri dishes containing starch-casein-agar medium (Kuster \& Williams, 1964) and $2.5 \%$ water-agar medium. Nystatin and cycloheximide $(50 \mu \mathrm{g} / \mathrm{ml}$ of each) were added to both media to suppress fungal growth (Williams \& Davies, 1965).Plates were incubated at $28^{0} \mathrm{C}$ for a maximum of three weeks. Actinomycetes growing on the media were isolated, purified and identified.

Identification of isolates: Each isolate was inoculated on specific ISP media (ISP 2, ISP 3, ISP 4 and ISP 5) according to Shirling \& Gottlieb (1966) to determine cultural and micromorphological characteristics (Williams et al, 1989; Holt et al., 1994).. The chemical composition of the cell wall from the isolates was also determined (Lechevalier \& Lechevalier, 1970; Goodfellow \& Minnikin, 1985).
Antimicrobial activity: Antimicrobial activity against the bacteria Staphylococcus aureus, Micrococcus luteus, Bacillus subtilis and the yeast Candida albicans, all from the collection of the " Departamento de Antibióticos, Universidade Federal de Pernambuco " were tested on ISP 3 solid medium according to Ichikava at al. (1971). Results were scored after 24-48 hours incubation at $37^{\circ} \mathrm{C}$.

\section{RESULTS AND DISCUSSION}

After a maximum of 21 days incubation, no microbial growth was observed on media inoculated with segments of leaves and roots derived from 7 day-old sampled plants. However, actinomycetes were observed emerging from roots and leaves segments of plants sampled 14 and 21 days after seed germination. The fact that actinomycetes were not isolated from plant tissues until after 7 days does not necessarily mean that they were not present; it could be that sufficient numbers were not present to allow isolation until this time. From a total of 53 isolates, $58.5 \%$ were obtained from leaves and the remaining $41.5 \%$ from roots. Results giving in Table 1 show that the most frequent genus found was Microbispora (33 isolates) followed by Streptomyces (6 isolates) and Streptosporangium (4 isolates). The remaining 10 isolates never bore reproductive structures and could not be identified. Sardi et al, (1992) found that from 499 endophytic actinomycetes isolated from 28 plant species about 96\% Streptomyces, $0.2 \%$ Streptosporangium and no Microbispora were reported. Although it can be pointed out that the media used in the present work and also by Sardi et al. (1992) are know to select for a few known species which may underestimate total population size, our results agree with those of Matsumoto et al (1998) which found after isolation and identification of actinomycetes from fallen leaves, that the genus Microbispora was the most frequently found, accounting for $44 \%$ of all isolates. 
Table 1 - Genera and number of endophytic actinomycetes isolated from Zea mays

\begin{tabular}{lccc}
\hline \multicolumn{1}{c}{ Genera } & \multicolumn{2}{c}{ Number of isolates from } & Total \\
& Leaves & Roots & \\
\hline Microbispora & 21 & 12 & 33 \\
Streptomyces & 3 & 3 & 6 \\
\hline Total & 31 & 22 & 53 \\
\hline
\end{tabular}

Results giving in Table 2 show that from the 53 isolates tested against bacteria and C. albicans, 23 of them $(43.4 \%)$ presented antimicrobial activity against one or more microorganisms used. Antimicrobial activity was also found in endophytic actinomycetes (Sardi et al,1992 and Maitan,1998) and thus, actinomycetes may play a role protecting the plant host against pathogenic microorganisms.

Table 2 - Antimicrobial activity of endophytic actinomycetes isolated from Zea mays against bacteria and yeast.

\begin{tabular}{|c|c|c|c|c|c|}
\hline Genera & Isolates* & S.aureus** & M.luteus & B.subtilis & C.albicans \\
\hline \multirow[t]{3}{*}{ Microbispora } & L3,L8,L12,L20,L26. & + & + & + & - \\
\hline & L29,R36,R39 & - & + & - & - \\
\hline & $\begin{array}{l}\text { L13,L14 } \\
\text { L16,L19,L28 }\end{array}$ & - & + & + & - \\
\hline \multirow[t]{5}{*}{ Streptomyces } & $\mathrm{L} 4$ & - & + & + & - \\
\hline & L30 & - & - & + & - \\
\hline & R45 & + & + & - & + \\
\hline & R50 & - & + & + & + \\
\hline & R51 & + & + & + & + \\
\hline Streptosporangium & L21 & + & + & - & - \\
\hline \multirow[t]{2}{*}{ Non identified } & L22. L25 & + & + & + & - \\
\hline & L5, L38 & + & + & + & - \\
\hline
\end{tabular}

$*$ L are isolates from leaves and $\mathrm{R}$ are isolates from roots.

$* *+$ and $-=$ inhibition and absence of inhibition respectively.

The results here described showed that actinomycetes can be isolated as endophytes not only inside maize roots but also inside leaves. The presence of actinomycetes mainly inside root tissues may play an important role in plant development and health. Several reports refer to actinomycetes acting in plant protection against pathogens and the influence of their metabolic products on plant growth and physiology (Katznelson \& Cole, 1965 ; Gupta et al,1995 and Kolomiets et al, 1997). In the present work, the presence of actinomycetes inside roots and leaves of a widely cultivated crop and from a tropical region was confirmed. Certain genera isolated as maize endophytes by us, were also found in the roots of plants from temperate climate (Sardi et al, 1992; Matsumoto et al, 1998). Other genera as Streptosporangium seems to be more frequently found in maize, from a tropical region than in other plants from temperate climate. The results are also as indication of the endophytic diversity that can be found and explored for biotechnological purposes.

\section{ACKNOWLEDGEMENTS}

This work was supported by FAPESP (Fundação de Amparo à Pesquisa do Estado de Sâo Paulo, Brazil). We also would like to acknowledge $\mathrm{CNPq}$ (Conselho Nacional de Desenvolvimento Científico e Tecnológico) for fellowships given to the authors.

\section{RESUMO}

Microrganismos endofíticos são frequentemente encontrados no interior de plantas cultivadas. Embora vários tipos de microrganismos endofíticos tenham sido isolados de milho (Zea mays) não existiam dados sobre certos grupos de actinomicetos obtidos a partir desta espécie de planta cultivada. No presente trabalho, actinomicetos endofíticos foram isolados de folhas e raízes de milho. Um total de 53 isolados foram obtidos sendo 31 deles a partir de folhas e 22 a partir de raízes. O gênero Microbispora foi o mais 
frequente (62\%), seguido dos gêneros Streptomyces e Streptosporangium. Dos actinomicetos isolados, 43,4\% apresentaram atividade antimicrobiana contra um ou mais microrganismos ensaiado.

\section{REFERENCES}

Azevedo, J.L. Microrganismos endofíticos. In : Ecologia Microbiana (I.S Meloj. L. Azevedo, Edts.) Jaguariuna, Editora Embrapa, 1998. 117-137

Baldani, J.I.; Olivares, F.L.; Hemerly, A. S.; Reis Jr., F.B.; Oliveira, A. L. M.; Baldani, V.D. L.; Goi, S.R.; Reis V.M.; Dobereiner, J. Nitrogen-fixing endophytes: Recent advances in the association with graminaceous plants grown in the tropics. In : Biological Nitrogen Fixation for the $21^{\text {st }}$ Century (C. Elmerich; A. Konderosi; W.E. Newton, Edts.) Dordrecht, Kluvier, Academic Publishers, 1997. 203296

Benson D. R.; Silvester, W.B. Biology of Frankia strains, actinomycete symbionts of actinorhizal plants. Microbiol, 1993. Rev. 28: 293-319

Bradbury, J.F. Guide to plant pathogenic bacteria. London, CAB International Mycological Institute Publ. 1986.

Fisher, P.J.; Petrini, O.; Lappin-Scott, H. M. The distribution of some fungal and bacteria endophytes in maize (Zea mays L.) New Phytol, 1992. 122: 299305

Goodfellow M.; Minnikin, D. E. Chemical Methods in Bacteria Systematics. London, Academic Press, 1985

Gupta, R.; Saxena, R.K.; Chaturverde, P.; Virdi, J. S. Chitinase production by Streptomyces viridificans: its potencial in fungi cell wall lysis. J. Appl. Bacteriol, 1995. 78: $378-383$

Hallmann, J.; Quadt-Hallmann, A. ; Mahaffe, W.F.; Kloepper, J.W. Bacterial endophytes in agricultural crops. Can. J. Microbiol, 1997. 43: 895-914

Holt, J.G.; Krieg, N.R.; Sneath, P.H. A.; Stanley,J.T.;Williams, S.T. Bergeys Manual of Determinative Bacteriology ( $9^{\text {th }}$ Ed.) Baltimore, Williams \& Wilkins, 1994

Ichikawa. T.; Ishikura, T. Ozaki, A. Improvement of kasugomycin-producing strain by the agar piece method and the prototroph method. Folia Microbiol, 1971. 16: 218-224

Isaac, S. Fungal-plant interactions. London, Chapman \& Hall, 1992.

Katznelson, H.; Cole S.E. Production of giberellin-like substances by bacteria and actinomycetes. Can. J. Microbiol, 1965. 11: 733-741
Kolomiets, E.I.; Zdor, N. A. Romanovskaya, T.V.; Lobanok, A. G. Certain aspects of the phytoprotective activity of Streptomyces flavescens an antagonist of phytopathogenic fungi. Appl. Biochem. Microbiol, 1997. 33: 451-454

Kuster, E.; Williams, S.T. Selection of media for isolation of streptomycetes. Nature, 1964. 202: 928929

Lechevalier M.P.; Lechevalier H. Chemical composition as a criterion in the classification of aerobic actinomycetes. Int. J. Syst. Bacteriol, 1970. 20: $435-443$

Leslie, J.F.; Pearson, C. A .S.; Nelson, P. E.; Tousson, T. A. Fusarium spp. from corn, sorghum and soybean fields in the central and eastern United States. Phytopathology, 1990. 80: 343-350

Maitan, V. R. Isolamento e caracterização de actinomicetos endofíticos isolados de Solanum lycocarpum (lobeira). Goiânia, Tese de Mestrado, Universidade Federal de Goiás, 1998.

Matsukuma, S.; Okuda, T.; Watanabe, S. Isolation of actinomycetes from pine litter layers. Actinomycetol, 1995. 8: 57-65

Matsumoto, A.;Takahashi, Y.; Mochizuki, M; Seino, A.; Iwai, Y.; Omura, S. Characterization of actinomycetes isolated from fallen leaves. Actinomycetol, 1998. 12: 46-48

Mundt, J. O.; Hinckle, N. F. Bacteria within ovules and seeds. Appl. Environ. Microbiol, 1976. 32: 694-698

Pereira, J. O, ; Azevedo, J.L.; Petrini, O. Endophytic fungi from stylosantes: a preliminary report. Mycologia, 1993. 85: 362-364

Pereira, J.O.; Carneiro-Vieira, M.L.; Azevedo, J.L. Endophytic fungi from Musa acuminata and their reintroduction in axenic plants. World J. Microbiol. Biotechnol, 1999. 15: 47-51

Redlin, S. C.; Carris, L. M. Endophytic fungi in grasses and woody plants. St. Paul, The American Phytopathological Society, 1996.

Sardi, P.; Saracchi, M.; Quaroni, B.; Borgonovi, G.E.; Merli, S. Isolation of endophytic Streptomyces strains from surface-sterilized roots. Appl. Environ. Microbiol, 1992. 58: 2691-2693

Shirling, E. B.; Gottlieb, D. Methods of characterization of Streptomyces species. Int. J. Sys. Bacteriol, 1966. 16: 313-349

Silva, A. C. Isolamento de fungos endofíticos de milho (Zea mays, L.) Piracicaba, Tese de Mestrado, Universidade de São Paulo, ESALQ, 1997.

Souza, A. Bactérias endofíticas de milho (Zea mays L.) e sua variabilidade genética analisada por RAPD. Piracicaba, Tese de Mestrado, Universidade de São Paulo, ESALQ, 1996. 
Stamford, T. L. M.; Coelho, L. C. B. B.; Araujo, J.M. Actinomicetos endofíticos isolados de tubérculos de jacatupé (Pachyrhisus erosus L., Urban) produtores de enzimas amilolíticas. Braz. J. Genet, 1997. 20: 200

Strobel, G. A.; Hess, W.M.; Ford, E.; Sidhu, R.S.W.; Yang, $\mathrm{X}$. Taxol from fungal endophytes and the issue of biodiversity. J. Ind. Microbiol, 1996. 17: 417-423

Strobel, G. A.; Long, D. M. Endophytic microbes embody pharmaceutical potential. Amer. Soc. Microbiol News, 1998. 64: 263-268
Williams, S. T.; Davies F. L. Use of antibiotics for selective isolation and enumeration of actinomycetes in soil. J. Gen. Microbiol, 1965. 38: 251-261

Williams, S. T.; Goodfellow, M.; Alderson, G. Genus Streptomyces. In: Bergey ' s Manual of Systematic Bacteriology, v.4 (S.T. Williams; M. E. Sharpe; J. Holt, Edts.) Baltimore, Williams and Wilkins, 1989. 2452-2468 